\title{
Extension to Brand Category, an Exploratory Investigation on Brand Extension Attitude
}

\author{
${ }^{1}$ Nigar Muhammad, ${ }^{2}$ Shabeeb Ahmad Gill, ${ }^{3}$ Majid Murad \\ ${ }^{1}$ Department of Textile Designing, National Textile University, Faisalabad, Pakistan \\ ${ }^{2}$ Department of Textile \& Clothing, G.C University Faisalabad, Faisalabad, Pakistan \\ ${ }^{3}$ Department of Business Administration, G.C University Faisalabad, Faisalabad, Pakistan
}

\begin{abstract}
The purpose of this research study is to identify the impact of the brand category on brand extension attitude. The concept of brand extension is used for the marketing of any brand which is associated with the firm. Most of the large industries are using well-known names to launch a new product range to earn more profile for the organization as well as to make new position rather than other brands. This study especially identified that those brand who want to extend the product range of brands. Data was collected from a convenience sample of different brand buyers in Faisalabad via surveys. The final sample consisted of 200 responses. Correlation, Linear regressions and ANOVA were used to test the hypotheses Results revealed that initial parent brand image has a positive relationship toward the brand extension attitude. Parent brand quality has a positive effect on brand extension attitude. Brand extension information toward the brand extension attitude is significantly impacted. The results provide some suggestion to marketers who want to expand their parent brand or launch fashion extension products.
\end{abstract}

Keywords: Brand extension category, Initial parent image, Perceived parent brand quality, Initial parent brand information, Brand extension attitude, Brands, Textile, Garments, Faisalabad, Pakistan

\section{Introduction}

Brand name elaborated by Smith \& Park (1992) can be an integral complement in consumption that enhances consumers' desires to pay. Where Cleary (1981) said that branding is essential to construct the product image. It affects, according to Arthur Rooney (1995) and Smith \& Park (1992), a product's perceived value or worth, tends to build customers' brand loyalty and increases the probability for brand extensions to succeed. Through constructing on consumers' brand awareness, knowledge and loyalty, brand extension strategies seek to enhance profits by promoting consumer purchases across product categories. As D. A. Aker (1996) discussed that brand extension has been one of the most common strategies to launch new products for decades.

All the strong brands according to D. Taylor (2006), are trusted and valued by users, consequently, an extension can leverage brand reputation to develop a worthy compelling proposition in a new market. According to D. A. Aaker \& Keller (1990), using a contemporary famous brand name to introduce new lines or types of products, decreases the need to create awareness and to communicate with users. Plans using extensions to facilitate adding new segments and markets have been broadly adopted. For instance, already established durable famous and fine brands (i.e. automobiles) have been leveraged to promote entering soft products types including home bedding, fashion clothing and accessory markets.

Fashion products, according to Kim (2012), including textiles, footwear, accessories, and different other goods that bear some characteristics, make them identifiable and distinguishable from other user products. Fashion products, according to Forney, Joo Park, \& Brandon (2005), can reflect self-image and they assume personal importance to the individual. This rich industry provides jobs to millions of people around the globe and affects almost all consumers today, more than ever before with our economy becoming more global. According to Solomon \& Rabolt (2006), 
fashion reflects one's culture and society; as a symbolic innovation, it reflects the way through which people define themselves. Diverse theorists Auty \& Elliott (1998) have presented the use of clothing as a code, a communication that enables a message to be prepared and selectively understood.

However, research, conducted by Shen, Bei \& Chu (2011), on finding elements forecasting the success of fashion garment extensions is still bounded. According to Zhang (2013), the current international automotive industry is very competitive, with production capacity far ahead than current demand. Many producers with relatively high fixed labour costs have to bound facilities and reduce fixed costs.

It is so difficult, according to Zhang (2013), for the automotive industry to keep their profitability sustainable. With their well-organized brands, auto organizations have been increasingly looking for opportunities to increase their demand for other goods types, in pursuit to broaden the halo of the brands. Now almost every car brand is growing its licensed merchandise plans, including specialty outdoor, sporting goods, apparel, eyewear, electronics, luggage, bikes and kids riding toys. For instance, BMW even launched a whole lifestyle collection, which features trendy apparel, such as polo shirts, T-shirts, hooded sweatshirts, and zip-up tops, as well as sporty caps, poncho-blankets, and light-weight jackets, as well as BMW gadgets, collectibles and travel accessories.

Faisalabad is the third biggest urban city after Karachi and Lahore. The region territory of Faisalabad is 5,856 square km with 12.786 million people; the city population is 7.14 million with an education rate of $66 \%$. Faisalabad has most prestigious brand outlets, e.g Chen-one, Metro, Khadi, Firdous, Charcol, Royal Tag, Cambridge, Eden Robe, Five Star etc.

\subsection{Problem Statement}

In Faisalabad there is a number of registered brands which provide precious products to the buyer and fulfill the expectation of the customer in branding industry. This study is to investigate brand extension category of industries which are going to extend a product range of brands. In this society most of the brands are not becoming successful in extending a brand category as well as quality of the brands, so the researcher thought that there is a gap of knowledge existing there in brand extension category of Faisalabad city.

\subsection{Objectives of the Study}

- To identify the influence of parent brand image on brand extension attitude;

- To investigate the influence of parent brand quality on brand extension attitude;

- To identify the influence of brand extension information on brand extension attitude.

\subsection{Research Questions}

- How much initial parent brand image influence the brand extension attitude?

- How much parent brand quality influence the brand extension attitude?

- How much brand extension information influence the brand extension attitude?

\subsection{Hypotheses of the Study}

H1: Initial parent brand image is positively associated with brand extension attitude;

H2: Parent brand quality is positively associated with brand extension attitude;

H3: Brand extension information is positively associated with brand extension attitude.

\section{Review of Literature}

\subsection{Brand Extension Attitude}

As D. A. Aaker \& Keller (1990); Völckner \& Sattler (2006) think, a brand extension succeeds if shoppers hold an optimistic attitude towards the extension, but some other researchers reflect that feat only occurs when consumers intend to purchase the extension. According to Lafferty (2007), O'Cass \& Grace (2004), a user holding a positive attitude toward a product is not the same as buying the extension. Corporations want to know consumers' attitude, however, their buying intentions are much more significant, because it tells about profits. Thus the consumers' purchase intention, or Acceptance, is the focus of the parent brand firms. 
As discussed by Solomon \& Rabolt (2006), fashion decision-making framework labels the last stages such as: assessment of substitutes (consumer compares several styles and brands of the products in terms of construction, country of origin, or added features) product choice (consumer chooses one product and tries it on) outcome (consumer buys the product and enjoys the purchase). Regarding this framework, after assessing a product, consumer holds a positive or negative attitude to the product, and his/her decision of buying is depended on the attitude.

Woodside \& Clokey (1974) identified that consumers' attitudes are affected by competitors' activity, as well as, numerous other information sources. They developed a multi-attribute/multi-brand model of attitude formation and systematically evaluated the process of brand attitude formation. The results of the (Woodside \& Clokey, 1974) study state that "brand choice was more accurately predicted when attitudes toward other brands were also considered." In summary, associations that are unique to the brand, strongly held, and favourably held, are vital for success. However, since the specific associations a consumer holds are dependent on personal values and individual purchase situations, managers must learn what they are and when they operate. In addition, competitive offerings blur the uniqueness of the brand's associations. Therefore, it is important, on a product by product and situation by situation basis, to assess consumers' relevant brand associations (Zhang, 2013).

\subsubsection{Horizontal extensions}

Typically, horizontal brand extensions either apply or extend an existing product's name to a new product in the same product class or to a product category new to the company. There are two varieties of horizontal brand extensions which differ in terms of their focus (Aaker and Keller, 1990). They are termed line extensions and franchise extensions. Line extensions involve a current brand name which is used to enter a new market segment in its product class. Diet Coke and Diet Pepsi are examples of line extensions since they focus on the diet conscious segment for colas not served by their parent products. In contrast, franchise extensions use a current brand name to enter a product category new to the company (Tauber, 1993). Jell-O Frozen Pudding Pops exemplifies a franchise extension from Jell-O gelatine dessert. Most of the recent research in brand extension has focused on horizontal extensions.

\subsubsection{Extension distance}

One brand extension variable studied recently is the distance of the extension from the core product. Close extensions may be in the same product category and share the same feature set as the parent product. Distant extensions may be in unrelated product categories and rely on overall quality associations from the parent for success. Horizontal extensions lend themselves to natural distancing. Distancing is the purposive increase in the perceptual distance of the extension from the core product. Unsuccessful horizontal extensions are less likely to damage the core brand than vertical extensions since horizontal extensions are often in different and more distant - product categories. Typically, consumers will recognize that such horizontal extensions are not closely related. The downside to distancing is that distancing reduces the amount or strength of the brand associations and reduces the halo effect of the extension. Horizontal extensions may suffer if the core and extension are perceived to be too distant from each other. Brand associations cannot stretch over too large a gulf. Research indicates that if the core product is perceived to be of high quality, and the "fit" between the core and extension is high, then brand attitudes toward the extension will be more favourable (Aaker and Keller, 1990). Without the perceived similarity between the parent and extension, consumers find it more difficult to attribute original brand associations to the extension.

\subsubsection{Vertical extensions}

In contrast, vertical extensions involve introducing a related brand in the same product category but with a different price and quality balance. They offer very little distancing. Vertical extensions offer management the quickest way to leverage a core product's equity. However, since the new product is in the same category, distancing is difficult and the risk of negative information is higher than with a horizontal extension. As a strategy, the vertical brand extension is widely practiced in many industries. For example, within automobile brands, the various models attempt to offer distinct pricequality bundles to attract a variety of market segments. Often a product will be extended in an attempt to garner more of the market.

\subsubsection{Feedback to parent brand}

Keller et al. (2011) and Martinez \& De Chernatony (2004) defined that brand families are sensitive to the evidence presented by the extension, and improved or diluted conferring with the calculation of the new extension group. Previous research by Martínez et al. (2009) and Alexander \& Colgate (2005) also presented consumers attitude towards 
the extension category has an outcome on the overall brand image. Basic point, according to Alexander \& Colgate (2005), is that consumers satisfied with retail brand extensions are progressively more satisfied with the parent brand. It was indicated by Keller et al. (2011) that brand extension may improve the parent brand image by "strengthening an existing brand association, improving the availability of an existing brand association, adding a new brand association or a combination of these". For example, it was found that a successful brand extension enhanced the observations of the skill and honesty of the parent brand (Keller \& Aaker, 1992).

\subsection{Initial Parent Brand Image}

Psychological researchers like Keller et al. (2011) suggest that persons do not purposely and separately assess each new stimulus to which they are visible; in its place they ordinarily assess a stimulus in period of whether they can categorize it as a member of a formerly distinct intellectual group. Thus it is argued that customers practice their knowledge of brands and goods to streamline assembly and understand their marketing atmosphere.

As founded by Lane (2000), exposure to a brand name or other stimuli by customers have higher effective favorite for the stimuli. If consumers saw a brand extension as carefully linked or alike to the brand category, they could simply transmit their current attitude about the parent brand to the extension, then straight imply the brand associations to more positive assessments of brand extensions. Martínez et al. (2009) and Yeung (2005) even found that if a brand suggests a strong positive sensitive attraction, consumers are likely to be less influenced by the perceived fit between the parent brand and the extension. Therefore, product introduction with a similar brand name can function as a lever in brand image, brand awareness and in general in reaching the brand equity in the established market (Zhang, 2013). Low cost and high possibility of success have led to selection of brand extension by more than $80 \%$ of the companies as a way of product marketing and services (Keller et al., 2011). The relation or linkage of an existing brand with a newly-named geographical phenomenon, a person or in this case a product, may affect the relations and linkage of the existing brand image. This effect can be positive, therefore memory and power increases. These relations and connections often happen as attitudes which are not very serious (Morrin, 1999).

\subsection{Perceived Parent Brand Quality}

It was elaborated by D. A. Aaker \& Keller (1990) that the next theory pursues to find out what issues show significant roles when customers assess the extension. Found that both a perception of fit between the original and the extension product categories and a perception of high quality for the parent brand led to more constructive extension assessments. The perceived quality D. A. Aaker \& Keller (1990), of the parent brand is one of the significant issues that affect the attitude toward the extension. Customers often think superior brands are more trustworthy and skilled. If the brand (Fedorikhin, Park, \& Thomson, 2008) is related to extraordinary quality, the extension may advantage consumers are ready to pay more for the brand extension and endorse it to others. As a result (Keller \& Aaker, 1992), even if they trust a comparatively distant extension that does not really fit with the parent brand, they may be keener to give a high-quality brand the advantage of the hesitation than a brand measured as normal quality.

\subsection{Brand Extension Information}

Defined by Keller et al. (2011), some relations with the parent brand may assist as a possible foundation of fit. The most researchers like MacInnis, Nakamoto, \& Mani (1992) consider that the more mutual and the less distinctive relations that exist, the superior the awareness of overall resemblance, whether based on product or non-product connected qualities and benefits. A number of research studies by Keller et al. (2011) have exposed that the facts delivered about brand extension, by "triggering selective retrieval from memory", may process the customer decision making and affect extension assessment. In overall Keller et al. (2011), the most effective plan seems to be one that identifies the type of information already noticeable for the brand in the minds of customers when they first consider the projected extension, and that highlights extra information they would then oversee or mistake. Keller \& Aaker (1992) stated that explaining briefly on exact extension attributes on which customers were uncertain or worried led to more constructive assessments. Bridges Keller et al. (2011), as well as Klink \& Smith (2001), found that providing evidence could progress insights of fit when customers alleged low fit between the brand and the extension, whichever by supporting an ignored root of fit or by talking a disturbing negative association. It was found by Lane (2000) that recapping an ad that induced principally brand associations could overawe negative insights of a highly dissimilar brand extension. Moreover, Keller et al. (2011), for be one that identifies the type of information already salient for the 
brand in the minds of customers when they first consider the planned extension, and that highlights extra information they would then oversee or mistake.

\section{IV.1}

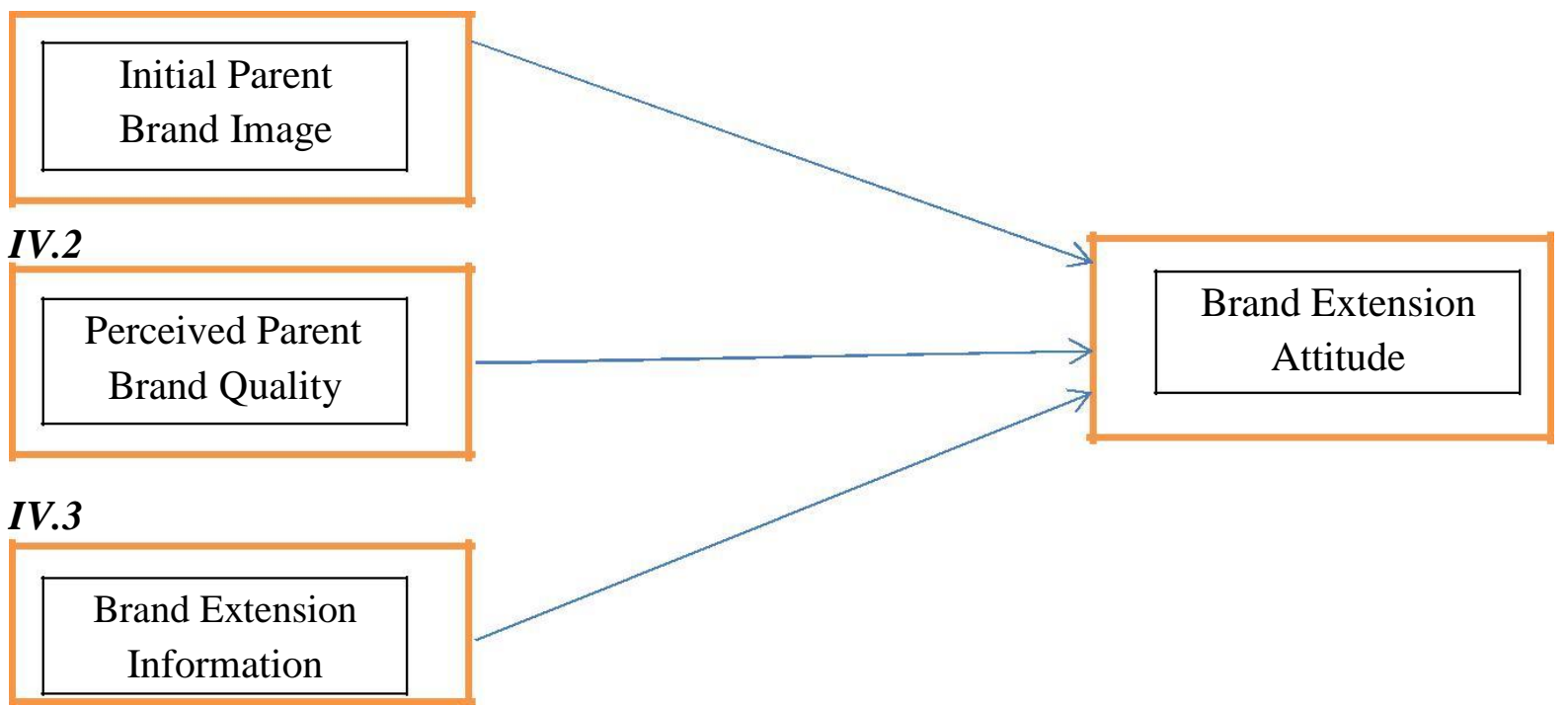

Figure 1: Theoretical Framework

\section{Materials and Methods}

\subsection{Research Design}

This study used the way to distribute the questionnaires among respondents. Data has been collected through questionnaires and administrated by the researcher. The data collection approach was non- probability sampling and sample size of 250 respondents taken. The population for this study consists of all brand sector of Faisalabad. The questionnaire was filled by the customer in the non-contrived conditions in their workplace and researcher interference was minimal. The core objective of this investigation is to find out the brand extension category on brand extension attitude of a brand sector of Faisalabad. To approach this purpose researcher selected the option of quantitative research type. Since no workable data relating this topic was available, so the researcher thought to apply a quantitative investigation. Therefore, researcher used exploratory research design because he wants to explore the importance of this topic for the prosperity of industry as well as the body of knowledge. All the findings and analysis are based on that quantitative data that has been collected through questionnaires. Through different appropriate statistical tools this data has been analysed i.e. descriptive analysis, correlation analysis and regression analysis.

\subsection{Sample Size}

It is already mentioned above that Faisalabad is the third biggest city of Pakistan. The data collection from customers of existing brands was really a tuff and the most time taking part of this investigation. In this task before data collection from each unit firstly researcher has to provide data collection permission letter from university to unit administrated then they did allow collecting the data for only research purposes. The researcher has visited 100 brands shop of Faisalabad and collected 250 questionnaires aggregately the questionnaire as the respondent had completed it and verified the completeness of this questionnaire at the same time.

\subsection{Sample Characteristics}

Sample characteristics are showing from following tables. Table No. 1 describes the gender share of the employees. Table No.2 demonstrates the age classes of employees and table No. 3 identified the $\%$ of that data which falls in diversified level of education changes from Matric to M. Phil \& above. The following table highlights the employee's characteristics from whom the data has been gathered. 
Gender of Respondents

Table 1: Gender of Customers

\begin{tabular}{|c|c|c|c|c|}
\hline & Frequency & Percent & Valid Percent & $\begin{array}{c}\text { Cumulative } \\
\text { Percent }\end{array}$ \\
\hline Male & 94 & 47.0 & 47.0 & 47.0 \\
Female & 106 & 53.0 & 53.0 & 100.0 \\
Total & 200 & 100.0 & 100.0 & \\
\hline
\end{tabular}

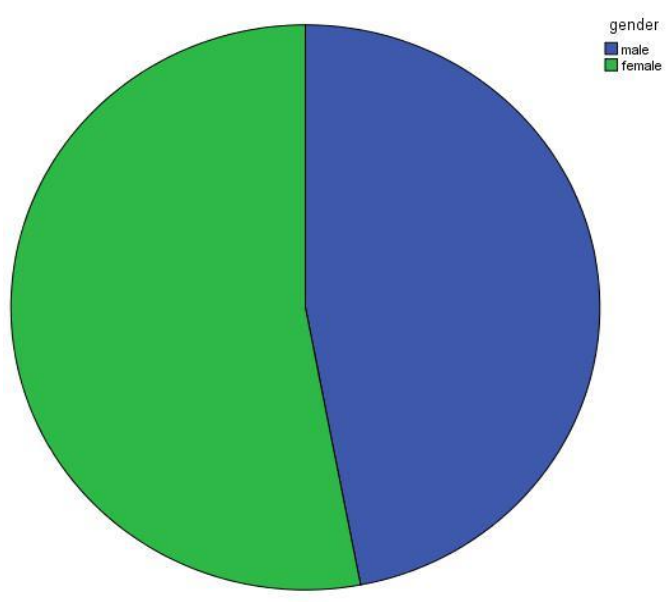

Figure 2: Gender of Customers

Age group of Respondents

Table 2: Age distribution of Customers

\begin{tabular}{|c|c|c|c|c|}
\hline & Frequency & Percent & Valid Percent & Cumulative Percent \\
\hline $10-20$ & 47 & 23.5 & 23.5 & 23.5 \\
$21-30$ & 60 & 30.0 & 30.0 & 53.5 \\
$31-40$ & 59 & 29.5 & 29.5 & 83.0 \\
$41-50$ & 34 & 17.0 & 17.0 & 100.0 \\
Total & 200 & 100.0 & 100.0 & \\
\hline
\end{tabular}

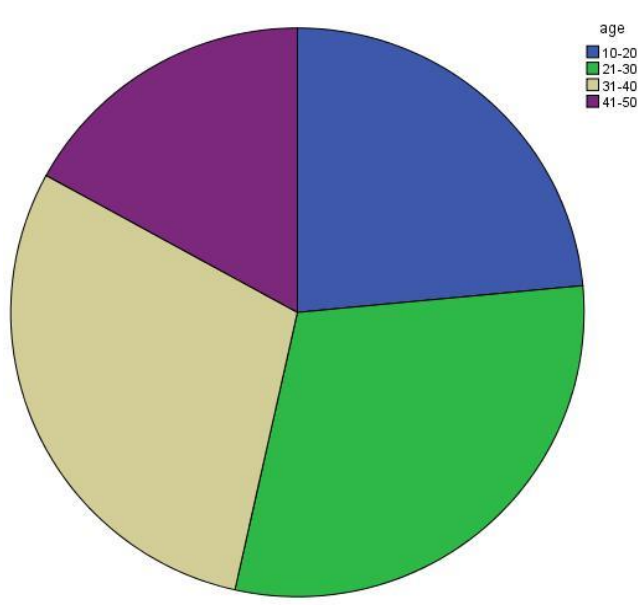

Figure 3: Age distribution of Customers 
Education of Respondents

Table 3: Customers education

\begin{tabular}{|l|c|c|c|c|}
\hline & Frequency & Percent & Valid Percent & Cumulative Percent \\
\hline matric & 63 & 31.5 & 31.5 & 31.5 \\
intermediate & 36 & 18.0 & 18.0 & 49.5 \\
graduation & 33 & 16.5 & 16.5 & 66.0 \\
masters & 63 & 31.5 & 31.5 & 97.5 \\
m.phil-above & 5 & 2.5 & 2.5 & 100.0 \\
Total & 200 & 100.0 & 100.0 & \\
\hline
\end{tabular}

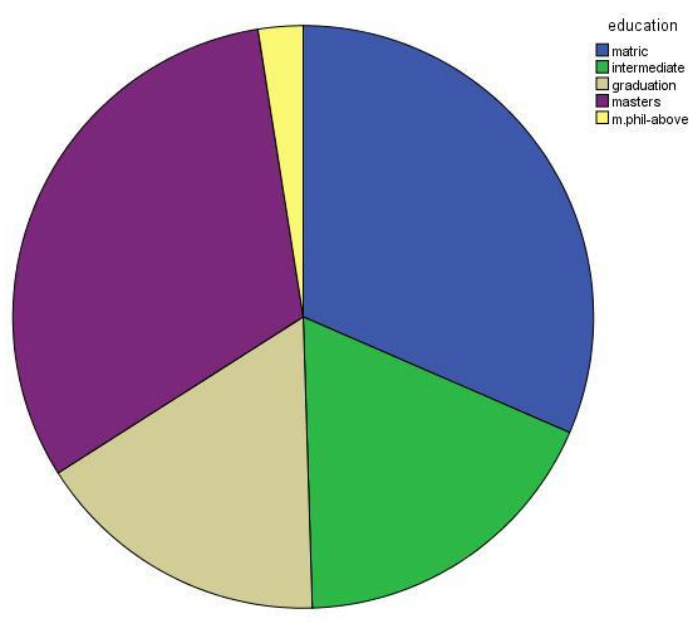

Figure 4: Customers education

\subsection{Instrumentation}

The questionnaire items in this research have been adopted from previous literature. Every item has been measured at five points as Likert scale and answers are ranked as 1=strongly disagree, $2=$ disagree, $3=$ neutral, 4=agree and 5=strongly agree. Every link and source have been mentioned below from where ever the items have been adopted. Some little modifications have been made in the questionnaire in order to make it easy and understandable for targeted employees. To estimate the only Independent variable of IPBI these items adopted from (Zhang, 2013) of this measurement include six items. For the measurement of the first independent variable (PPBQ) (Zhang, 2013) three has been adopted from this study. To measure the BEI that is the second independent variable five items has been also adopted from (Zhang, 2013) study. This variable also adopted from the same study (Zhang, 2013) from which other two dependent variables are adopted and three items for this variable. (Zhang, 2013), three most usable demographic variables like gender, age and education for developing people equity has been adopted.

\subsection{Reliability Analysis}

The results of Cronbach`s alphas in table no. 3.4 highlights three independent variables IPBI, PPBQ and PBI as well as our dependent variable of BEA. My first independent variable "initial parent brand image" IPBI was consisted of six items with reliability score $(\alpha=.64)$. Four items were used for the second independent variable of "perceived parent brand quality" PPBQ with Cronbach`s alpha score $(\alpha=.75)$. At the end, third and last independent variable "Brand extension information" with three items showed the value of Cronbach's alpha $(\alpha=.85)$. 
Nigar Muhammad, Shabeeb Ahmad Gill, Majid Murad

Table 4: Reliability Analysis

\begin{tabular}{|c|c|c|c|}
\hline \multirow{2}{*}{ Variables } & \multicolumn{3}{|c|}{ Reliability } \\
\cline { 2 - 4 } & Items & Cronbach $\alpha$ & Reference \\
\hline $\boldsymbol{B}$ IPBI & 3 & .65 & $($ Zhang, 2013) \\
\hline $\boldsymbol{P P B Q}$ & 6 & .64 & $($ Zhang, 2013) \\
\hline $\boldsymbol{B E I}$ & 3 & .75 & $($ Zhang, 2013) \\
\hline Total & 5 & .85 & (Zhang, 2013) \\
\hline
\end{tabular}

\section{Result and Discussion}

\subsection{Data Analysis}

The researcher used SPSS version 20 for the analysis of collected data. This investigation has been used different statistical tools to evaluate above formulated hypothesis. Some tables' used and a better description of data makes it easy to understand, evaluate and useable. And the crux of this research article precisely interprets the suggested goals and the results following the application in firm`s environment.

Table 5: Descriptive Statistics

\begin{tabular}{|c|c|c|c|c|c|}
\hline & $\mathrm{N}$ & Minimum & Maximum & Mean & Std. Deviation \\
\hline Gender & 200 & 1 & 2 & 1.53 & .500 \\
\hline Age & 200 & 1 & 4 & 2.40 & 1.027 \\
\hline Education & 200 & 1 & 5 & 2.55 & 1.290 \\
\hline Brand Extension Information & 200 & 11.00 & 22.00 & 17.2850 & 2.42138 \\
\hline Initial Brand Image & 200 & 11.00 & 28.00 & 23.7200 & 4.55691 \\
\hline Perceived Parent Brand Quality & 200 & 7.00 & 14.00 & 12.1050 & 1.72594 \\
\hline Brand Extension Attitude & 200 & 8.00 & 15.00 & 12.5450 & 1.75309 \\
\hline $\mathrm{N}$ & 200 & & & & \\
\hline
\end{tabular}

Table 6: Correlation Matrix of Variables

\begin{tabular}{|ll|r|r|r|r|}
\hline & & $\begin{array}{r}\text { Brand Extension } \\
\text { Information }\end{array}$ & $\begin{array}{r}\text { Initial Brand } \\
\text { Image }\end{array}$ & $\begin{array}{r}\text { Perceived Parent } \\
\text { Brand Quality }\end{array}$ & $\begin{array}{c}\text { Brand Extension } \\
\text { Attitude }\end{array}$ \\
\hline $\begin{array}{l}\text { Brand Extension } \\
\text { Information }\end{array}$ & Correlation & 1 & & \\
$\begin{array}{l}\text { Initial Brand Image } \\
\text { Perceived Parent Brand }\end{array}$ & Correlation & $.608^{* *}$ & & \\
Quality & Correlation & $.688^{* *}$ & $.614^{* *}$ & \\
Brand Extension Attitude & Correlation & $.707^{* *}$ & $.512^{* * *}$ & $.725^{* * *}$ \\
\end{tabular}

${ }^{*} p<.05, n=$ Total Respondents $=200, I P B I=$ Initial parent brand image, $P P B Q=$ Parent brand quality, BEI = Brand extension information, $B E A=$ Brand extension attitude

**. Correlation is significant at the 0.01 level (2-tailed). 
Table 7: Results of Linear Regression Analysis

\begin{tabular}{|l|c|c|c|c|c|c|}
\hline \multirow{2}{*}{\multicolumn{1}{|c|}{ Predictors }} & \multicolumn{6}{|c|}{ Linear Regression Analysis } \\
\cline { 2 - 8 } & R Square & $\boldsymbol{F}$ & Beta & $\boldsymbol{T}$ & Sig. & $\begin{array}{c}\text { Empirical } \\
\text { Evidence }\end{array}$ \\
\hline H1: IPBI ---BEA & .499 & 197.49 & .707 & 14.053 & .000 & Accepted \\
\hline H2: PPBQ ---BEA & .262 & 70.244 & .512 & 8.381 & .000 & Accepted \\
\hline H3: BEI ---BEA & .526 & 219.42 & .725 & 14.813 & .000 & Accepted \\
\hline
\end{tabular}

Above table shows results of regression analysis model, accordingly with F value of 197.4 (p < 0.01) hypothesis H1 (a) was significant and positive. It represents the fitness of model. Other measures like R-square $=.499$, mean that independent variable 'Initial Parent Brand Image (IPBI))' IPBI explained 49.9\% variation in the dependent variable “Brand Extension Attitude” BEA. Results also explicated that 'Initial Parent Brand Image (IPBI))' IPBI has the positive impact on 'Brand Extension Attitude' BEA through standardized beta value $(p<0.01, \beta=.512)$. It shows that one unit increase in Initial Parent Brand Image (IPBI)) will bring $46.3 \%$ increase Brand Extension Attitude (BEA). The individual association of IPBI with BEA is $(\mathrm{p}<0.01, \mathrm{t}=14.0)$ that is also very considerable. Based on these results of regression analysis, hypothesis H1 (a) was accepted.

For second predictor it shows results of regression analysis model, accordingly with F value 70.2 ( $p<0.01)$ hypothesis $\mathrm{H} 2$ (a) was significant and positive. It represents the fitness of model. Other measures like R-square $=.262$, means that independent variable 'Perceived Parent Brand Quality' PPBQ explained 26.2\% variation in the dependent variable "Brand Extension Attitude" BEA. Results also explicated that 'Perceived Parent Brand Quality' PPBQ has the positive impact on 'Brand Extension Attitude' BEA through standardized beta value $(p<0.01, \beta=.197)$ it shows that one unit increase in Perceived Parent Brand Quality' PPBQ will bring 19.7\% increase Brand Extension Attitude' BEA. The individual association of PPBQ with BEA is $(p<0.01, t=8.38)$ that is also very considerable. Based on these results of regression analysis, hypothesis $\mathrm{H} 2$ (a) was accepted.

Finally, for the last predictor, it shows results of regression analysis model, accordingly with F value 219.4 (p $<0.01$ ) hypotheses H3 (a) was significant and positive. It represents the fitness of model. Other measures like R-square $=.562$, means that independent variable 'Brand Extension Information (BEI) explained 56.2\% variation in the dependent variable "Brand Extension Attitude (BEA). Results also explicated that 'Brand Extension Information (BEI) has the positive impact on 'Brand Extension Attitude (BEA) through standardized beta value $(p<0.01, \boldsymbol{\beta}=.736)$ it shows that one unit increase in 'Brand Extension Information (BEI) will bring $47.8 \%$ increase Brand Extension Attitude (BEA). The individual association of BEI with BEA is $(p<0.01, t=14.8)$ that is also very considerable. Based on these results of regression analysis, hypothesis $\mathrm{H} 3$ (a) was accepted.

\subsection{Discussion}

The main objective of this study is to identify the brand extension category on brand extension attitude industries of Faisalabad. The results of my research output indicated that brand image is positively associated with the brand extension attitude. Brand quality is positively associated with brand extension attitude. Brand information is positively associated with the brand extension attitude. Most of the previous research indicated that by (D. Taylor, 2006) brand extension and brand extension attitude has a positive relationship between each other. My research study result match with the result of (Keller et al., 2011) that brand image has a positive relationship with the brand extension of any industry which wants to launch a new product in the market. As per finding of (Lei, Dawar, \& Lemmink, 2008) brand quality directly impacts the brand extension attitude because the quality is the basic essential tool for promoting the every brand worth. Brand information and brand extension attitude have a positive relationship between each other (Zhang, 2013). Brand information of every buyer who wants to launch new brand extension must have complete product knowledge and information about the brand.

The result of the first hypothesis of the study is that $\mathrm{R}$ square .499 and fitness of the model is 197.4 , B mean Beta .707. This result support with the result of the study of D. Taylor, (2006). The result includes between dependent variable 
and independent variable which is brand image and brand attitude. Previously multiple studies on brand image effect studies have failed to consider inter-relationships among explanatory variables. On the other hand, studies that consider inter-relationships fail to observe a brand image effect of fit towards general brand extension attitude.

The second hypothesis of the study is indicated that $\mathrm{R}$ square .262, Fitness of the model is 70.2 and the Beta .512 . This result is supported with the study Bottomley and Holden; Broniaczyk and Alba; Grime et al.; Keller and Aaker; Milberg et. al (2001). The third hypothesis of the study is indicated that $\mathrm{R}$ square .523, Fitness of the model is 219.4 and the Beta .725. This result support with the study of the Martinez and Chernatony; Martinez, et al.; Pina et al (2009). This study has clarified its likely true position.

\section{Summary}

The finding is that favorable brand image towards brand extension attitude directly leads to acceptance of brand extension, and that favourable attitudes occur when brand extensions are made with high brand concept consistency, and consumers hold favourable perceptions of parent brand image. The more product knowledge consumers know about the category in which the parent brand has been established or the category into which the brand extends, the higher perceived fit between the parent brand and brand extension. These findings are consistent with the findings in the previous literature (D. A. Aaker \& Keller, 1990; Lafferty, 2007; O'Cass \& Grace, 2004; Solomon \& Rabolt, 2006). Perceived parent brand quality does affect consumers' attitude towards brand extension indicating that "product-feature similarity" between fashion brands and fashion categories does play a role in consumers' attitude formation toward brand extensions. Generally, consumers often see high-quality brands as more credible, expert, and trustworthy. As a result, even if they believe a relatively distant extension does not really fit with the brand, they may be more willing to give a high-quality brand the benefit than a brand they see as average in quality (Broniarczyk \& Gershoff, 2003). However, all brands have boundaries. In the case of extending the auto brand to fashion categories, when perceived fit is low, the consumer may question the ability of an automobile company to make attractive fashion products, as a result, the transfer of a brand's perceived quality may be inhibited.

Consumers' attitude towards brand extension does affect parent brand image, neither the overall attitude toward parent brand, when a fashion brand extends into fashion categories. It may also be due to the low product-feature fit. (Loken \& John, 1993) found that perceptions of quality for a parent brand in the health and beauty aids area decrease with the hypothetical introduction of a lower-quality extension in a similar product category. However, quality perceptions of the parent brand were affected when the proposed extension was in a dissimilar product category. Similarly, Keller \& Aaker (1992) sound that successful extensions in dissimilar product categories did not affect evaluations of the parent brand. On the other hand, (Morrin, 1999) examined the impact of brand extensions on the strength of parent brand associations in memory and found that the advertised introduction of an extension did not improve the memory of the parent brand to the same level from the advertising directly promoting the parent brand. Thus, we can conclude that extending into fashion categories, whether successful or not, does not affect the parent brand. In other words, for automobile brands, it is a safe decision to license the brand name for launching fashion product lines, in order to increase profits without diluting parent brand image.

Different amounts and types of extension product information affect consumers' perceived fit between parent brand and brand extension, and their attitude towards brand extension. A number of studies have shown that the information provided about brand extension may frame the consumer decision process and affect extension evaluations. For instance, (Klink \& Smith, 2001) found that providing information could improve perceptions of fit when consumers perceived low fit between the brand and the extension. Our findings also supported these previous research findings. However, our results did support (Keller et al., 2011) findings that elaborating briefly on specific extension attributes about which consumers were uncertain or concerned led to more favourable evaluations. It may be due to individual differences, the uniqueness of fashion products and competitive fashion market. Consumers evaluate fashion products based on the preferred image, quality, design/beauty, and/or colour/style dimensions (Forney et al., 2005). A fashion extension may benefit from the parent brand, but the baseline is that the extension products should meet consumers' requirements. The finding on Brand Extension Attitude is not fully consistent with previous findings (D. A. Aaker \& Keller, 1990; Broniarczyk \& Gershoff, 2003; Martínez et al., 2009) and this requires further research. 


\subsection{Practical Implications}

Brand Extension category is a new concept in Pakistani brand industry as well as in corporate sector. This is an emerging combination of brand to brand extension that provides a brand real chance to gain competitive advantages rather than other brands. Through its spiritual application in different brand sectors of Pakistani brand sector we can enjoy a real increasing trend regarding a brand extension. This research investigation indicates some useful implications for Pakistani brands as we found a very strange relation between (IPBI and BEA, PPBQ and BEA, BEI and BEA) of the brand sector. There is a large number of registered and non-registered brand across the country if we become successful in the implementation of these brand extension practices even on $70 \%$ brands then it can give a rapid boost to our economy. Results demonstrate that if there exists knowledge of brand image, brand quality and brand information of customers these practices could take the brand on the track of prosperity and growth. These all practice is to examine customer feedback about the brand quality and brand image. This research tried to provide a better understanding of consumers' evaluation of a fashion brand extending into fashion categories, by comprehensively reviewing previous research relating to this subject, and developing a research rationale. Empirical data were collected through a survey to assess how consumers perceive fashion extensions of fashion brands. Finally, regression analysis of variance was used to test the proposed research model and hypotheses. To better understand consumers' perception of brand extension, especially when a brand extends into fashion categories, our thinking should not be limited to the currently available theories. The findings of this research provide practical suggestions for durable product brands because the results show that they could license their brand names to launch fashion products without the risk of diluting the brand image. To maximize the consumers' acceptance of the fashion extension, an auto company should choose the appropriate categories to enter the market. In addition, the findings from comparing the differences of brand extension attitude among groups provide a guide to launching fashion products for brands. Consumers tend to have a more favourable attitude towards the fashion extension when actually seeing the picture of the products, whether commercial advertising pictures or just basic plain views of the product. Even though the basic view of the products does not fit with their imagination of the extension products, consumers still hold a more favourable attitude towards the extension than those who did not see the product pictures. Thus, our suggestions for introducing auto brands' fashion extensions are: (1) the company should provide sufficient repetition of visual advertisements to consumers, and (2) the advertisement should address parent brand associations while focusing on the product itself. One of the most interesting and unexpected findings is that consumers' attitude towards the brand extension is not significantly related to the parent brand quality. Generally, the extension benefits more if the parent brand is considered high-quality. It may be due to the uniqueness of fashion products. Compared with other categories, fashion products evoke more symbolic meaning. When consumers make a purchase decision of fashion products, they don't just consider the quality, instead, their decision-making is more based on the preferred image, quality, design/beauty, and/or colour/style dimensions (Forney et al., 2005). Although consumers may still transfer the association of "high-quality" to the fashion extension, they may rely more on other symbolic features. Thus, our suggestion for designing the fashion products under a fashion brand name is to pay more attention to ensure the fashion product fit the parent brand image, as well as be attractive and stylish.

\subsection{Ethics and Scope of Research}

The above-expressed system for exploration is chosen to accomplish the goals of this examination so expressed destinations require experimental procedures, the information accumulated as surveys and the further measurable methods connected e.g. unwavering quality examination. There was the deliberate help of every individual in this research investigation. There was no discrimination on the basis of gender, education, ethnics, sects, age or status. The questionnaires were distributed with their consent. The researcher never asks personal and secret questions to correspondents and this practice has been exercised in a much-cooperated environment.

\subsection{Limitations and Future Directions}

It has been explained by (Ghauri \& Cateora, 2010) that it is very essential for educational study to describe the limitation of the research investigation. So it is much important to curse here the limitation of the current research study before going future. This research study is investigating the brand extension category on brand extension attitude of branding sector of Faisalabad. In the further research may focus on the impact of individual and cultural differences in consumers' perception of fashion extensions. This study is measured and explained the brand extension of brand sector of Faisalabad. In future the sector of brand can be changed from brand to sports, surgical good and someone else. This investigation has formulated a direct and significant linkage between the application of brand extension category and brand extension attitude in a sample of Faisalabad brand sector. 
Anyhow it is essential to acknowledge different limitations of the investigation. Firstly, the short sample of firms was taken $(n=200)$. In order to check the generalization of results, the same research has to implement on a large sample. Secondly, because of short time and scarce resource this study was conducted cross-sectional rather than observe the brand extension over the time so longitudinal study is recommended for further research. Furthermore, my investigation only conducted in the universe of Faisalabad so in order to implement the findings of study on any other universe conscious approach has to follow. Apart from these limitations this investigation has made significant input regarding theoretical and practical in the body of knowledge. The limitation is there in order to its input on the brand extension category on brand extension attitude regarding theoretical dimension. From a practical dimension the investigation has added a significant relation for brands need to improve their performance.

\subsection{Recommendations for Future Research}

Several suggestions for future research on brand extending into fashion categories are offered. One recommendation is to take individual differences into account. Specifically, brand engagement deserves more study because the importance of brands in one's life may vary. The parent brand plays a dominant role in brand extension research, thus, the group of consumers who just do not care about brands at all may not be considered as the target market of the brand extension. These consumers should be identified in future research.

Another recommendation is to take other types of fashion brands into account, especially functional/luxury, budget/prestige, and brand personality. Literature shows that consumers may perceive fit between the parent brand and brand extension based on the evaluation of those factors (J. L. Aaker, 1997; Batra, Lenk, \& Wedel, 2010; Keller et al., 2011; Park et al., 1991). The third recommendation is to take cultural differences into account. Fashion brands usually target the global market. However, successful and popular products in one area may not have a same performance in another area of the world, due to cultural differences.

Monga \& John (2007), found that consumers from Asian cultures (such as Pakistan) have a more holistic style of thinking and perceive higher levels of extension fit than do consumers from Western cultures (such as United States) who have a more analytical style of thinking. Thus, examining the impact of cultural differences on brand extension success may help auto brands to extend further.

\section{References}

- Aaker, David A. (1996). Measuring brand equity across products and markets. California management review, 38(3), 102-120, CrossRef

- Aaker, David A, \& Keller, Kevin Lane. (1990). Consumer evaluations of brand extensions. The Journal of Marketing, 27-41, CrossRef

- Aaker, Jennifer L. (1997). Dimensions of brand personality. Journal of marketing research, 347-356, CrossRef

- Alexander, Nicholas, \& Colgate, Mark. (2005). Customers' responses to retail brand extensions. Journal of Marketing Management, 21(3-4), 393-419, CrossRef

- Auty, Susan, \& Elliott, Richard. (1998). Fashion involvement, self-monitoring and the meaning of brands. Journal of Product \& Brand Management, 7(2), 109-123, CrossRef

- Batra, Rajeev, Lenk, Peter, \& Wedel, Michel. (2010). Brand extension strategy planning: empirical estimation of brand-category personality fit and atypicality. Journal of marketing research, 47(2), 335-347, CrossRef

- Bottomley, Paul A, \& Holden, Stephen JS. (2001). Do we really know how consumers evaluate brand extensions? Empirical generalizations based on secondary analysis of eight studies. Journal of marketing research, 38(4), 494-500, CrossRef

- Bridges, Sheri, Keller, Kevin Lane, \& Sood, Sanjay. (2000). Communication strategies for brand extensions: Enhancing perceived fit by establishing explanatory links. Journal of Advertising, 29(4), 1-11, CrossRef

- Broniarczyk, Susan M, \& Gershoff, Andrew D. (2003). The reciprocal effects of brand equity and trivial attributes. Journal of marketing research, 40(2), 161-175, $\underline{\text { CrossRef }}$ 
- Fedorikhin, Alexander, Park, C Whan, \& Thomson, Matthew. (2008). Beyond fit and attitude: The effect of emotional attachment on consumer responses to brand extensions. Journal of Consumer Psychology, 18(4), 281-291, CrossRef

- Forney, Judith C, Joo Park, Eun, \& Brandon, Lynn. (2005). Effects of evaluative criteria on fashion brand extension. Journal of Fashion Marketing and Management: An International Journal, 9(2), 156-165, CrossRef

- Ghauri, Pervez N, \& Cateora, Philip R. (2010). International marketing: McGraw-Hill Higher Education.

- Keller, Kevin Lane, \& Aaker, David A. (1992). The effects of sequential introduction of brand extensions. Journal of marketing research, 35-50, CrossRef

- Keller, Kevin Lane, Parameswaran, MG, \& Jacob, Isaac. (2011). Strategic brand management: Building, measuring, and managing brand equity: Pearson Education India.

- Kim, HaeJung. (2012). The dimensionality of fashion-brand experience: Aligning consumer-based brand equity approach. Journal of Fashion Marketing and Management: An International Journal, 16(4), 418-441, CrossRef

- Klink, Richard R, \& Smith, Daniel C. (2001). Threats to the external validity of brand extension research. Journal of marketing research, 38(3), 326-335, CrossRef

- Lafferty, Barbara A. (2007). The relevance of fit in a cause-brand alliance when consumers evaluate corporate credibility. Journal of Business Research, 60(5), 447-453, CrossRef

- Lane, Vicki R. (2000). The impact of ad repetition and ad content on consumer perceptions of incongruent extensions. Journal of Marketing, 64(2), 80-91, CrossRef

- Lei, Jing, Dawar, Niraj, \& Lemmink, Jos. (2008). The impact of brand relatedness on negative spillover effects in brand portfolios. NA-Advances in Consumer Research Volume 35.

- Loken, Barbara, \& John, Deborah Roedder. (1993). Diluting brand beliefs: when do brand extensions have a negative impact? The Journal of Marketing, 71-84, CrossRef

- MacInnis, Deborah J, Nakamoto, Kent, \& Mani, Gayathri. (1992). Cognitive Associations and Product Category Comparisons: The Role of Knowledge Structure and Context. Advances in Consumer Research, 19(1).

- Martinez, Eva, \& De Chernatony, Leslie. (2004). The effect of brand extension strategies upon brand image. Journal of consumer marketing, 21(1), 39-50, CrossRef

- Martínez, Eva, Montaner, Teresa, \& Pina, José M. (2009). Brand extension feedback: The role of advertising. Journal of Business Research, 62(3), 305-313, CrossRef

- Monga, Alokparna Basu, \& John, Deborah Roedder. (2007). Cultural differences in brand extension evaluation: The influence of analytic versus holistic thinking. Journal of Consumer Research, 33(4), 529-536, CrossRef

- Morrin, Maureen. (1999). The impact of brand extensions on parent brand memory structures and retrieval processes. Journal of Marketing Research, 517-525, CrossRef

- O'Cass, Aron, \& Grace, Debra. (2004). Exploring consumer experiences with a service brand. Journal of Product \& Brand Management, 13(4), 257-268, CrossRef

- Park, C Whan, Milberg, Sandra, \& Lawson, Robert. (1991). Evaluation of brand extensions: the role of product feature similarity and brand concept consistency. Journal of consumer research, 185-193, CrossRef

- Shen, Yung-Cheng, Bei, Lien-ti, \& Chu, Chia-Hsien. (2011). Consumer evaluations of brand extension: The roles of case-based reminding on brand-to-brand similarity. Psychology \& Marketing, 28(1), 91-113, CrossRef

- Smith, Daniel C, \& Park, C Whan. (1992). The effects of brand extensions on market share and advertising efficiency. Journal of Marketing Research, 29(3), 296, CrossRef

- Solomon, MR, \& Rabolt, NJ. (2006). Consumer Behavior in Fashion (SH Lee., MS Kim., JS Whang, Trans.). Seoul: Sigma press.(Original work published 2004).

- Taylor, David. (2006). Brand Stretch: Why 1 in 2 Extensions Fail, and How to Beat the Odds: John Wiley \& Sons.

- Taylor, Valerie A, \& Bearden, William O. (2002). The effects of price on brand extension evaluations: The moderating role of extension similarity. Journal of the Academy of Marketing Science, 30(2), 131-140, $\underline{\text { CrossRef }}$ 
- Völckner, Franziska, \& Sattler, Henrik. (2006). Drivers of brand extension success. Journal of marketing, 70(2), 18-34, $\underline{\text { CrossRef }}$

- Woodside, Arch G, \& Clokey, James D. (1974). Multi-attribute/multi-brand models. Journal of Advertising Research.

- Yeung, Catherine. (2005). The role of brand-elicited affect in brand extension evaluations. NA-Advances in Consumer Research Volume 32.

- Zhang, Langchao. (2013). Extending to Fashion Category: An Exploratory Study on an Auto Brand Extension. Beijing Institute of Fashion Technology 